Received: December 23, 2016 Accepted: January 08, 2017 Published: January 22, 2017

\title{
Increased Neuronal Depolarization Evoked by Autoan- tibodies in Diabetic Obstructive Sleep Apnea: Role for Inflammatory Protease(s) in Generation of Neurotoxic Immunoglobulin Fragment
}

\author{
Mark B. Zimering ${ }^{1,2, *}$, Zui Pan ${ }^{3}$ \\ ${ }^{1}$ Veterans Affairs New Jersey Healthcare System, East Orange, NJ \\ ${ }^{2}$ Endocrinology, Rutgers-Robert Wood Johnson Medical School, New Brunswick, NJ \\ ${ }^{3}$ College of Nursing and Health Innovation, University of Texas at Arlington, Arlington, \\ TX
}

*Corresponding author: Mark B. Zimering, Medical Service (111), Veterans Affairs New Jersey Healthcare System, Lyons, NJ 07939, USA, Tel: 908 647-0180; FAX: 908 604-5249; E-mail: mark.zimering@va.gov

\section{Abstract}

\subsection{Aim}

Obstructive sleep apnea increases in diabetes and morbid obesity. We tested a hypothesis that circulating autoantibodies in adult type 2 diabetes which increase in association with morbid obesity are capable of causing long-lasting neuronal depolarization and altered calcium release in mouse atrial cardiomyocytes.

\subsection{Methods}

Protein-A eluates from plasma of 14 diabetic obstructive sleep apnea patients and 17 age-matched diabetic patients without sleep apnea were tested for effects on depolarization and neurite out growth in N2a mouse neuroblastoma cells. The mechanism of autoantibodymediated neurite outgrowth inhibition was investigated in co-incubation experiments of diabetic obstructive sleep apnea autoantibodies with specific antagonists of G-protein coupled receptors or the RhoA/ Rho kinase signaling pathway. Following long-term storage of the protein-A eluates (to allow spontaneous proteolysis and IgG subunit dissociation), plasma autoantibodies from diabetic obstructive sleep apnea, cancer or control patients were compared for enhancement of inhibitory effects on endothelial cell survival. Size exclusion chromatography performed (in the presence or absence of a specific membrane type 1- matrix metalloproteinase inhibitor) was used to characterize the IgG autoantibody subunit(s) or fragments associated with peak neurotoxicity in diabetic obstructive sleep apnea.
1.3 Results

Diabetic obstructive sleep apnea $(n=14)$ autoantibodies caused a significant increase $(P=0.01)$ in membrane depolarization in N2a mouse neuroblastoma cells compared to control diabetic patients $(n=15)$ not suffering with obstructive sleep apnea. Process extension in N2A mouse neuroblastoma cells was significantly inhibited $(P=0.01$ ) by diabetic obstructive sleep apnea $(\mathrm{n}=9)$ autoantibodies compared to effects from identical $10 \mu \mathrm{g} / \mathrm{mL}$ concentrations of control diabetic autoantibodies in patients without obstructive sleep apnea. Ten micromolar concentrations of SCH-202676, a G-protein coupled receptor antagonist $(n=5)$ or ten micromolar concentration of Y27632, a selective Rho kinase inhibitor $(n=6)$, each significantly prevented (P $<0.001$ ) neurite outgrowth inhibition by diabetic obstructive sleep apnea autoantibodies. Autoantibodies in representative patients with obstructive sleep apnea and either atrial fibrillation or left ventricular hypertrophy evoked acute large increases in intracellular $\mathrm{Ca}^{2+}$ in $\mathrm{HL}-$ 1 mouse atrial cardiomyocytes. The magnitude of intracellular $\mathrm{Ca}^{2+}$ release was dose-dependently significantly correlated to the electrocardiographic Cornell voltageduration product. Gel filtration of diabetic obstructive sleep apnea autoantibodies revealed peak neurotoxicity associated with MWs corresponding to IgG light chain dimer(s), monomers or half-light chains as well as a novel $\sim 5.5 \mathrm{kD}$ putative light chain fragment. 


\subsection{Conclusions}

These results suggest that diabetic obstructive sleep apnea autoantibodies may induce strong depolarization in neuronal cells and alter $\mathrm{Ca}^{2+}$ signaling in atrial cardiomyocytes consistent with a role in pathophysiology in subsets of diabetic obstructive sleep apnea having comorbid atrial fibrillation or another clinically significant cardiac rhythm disturbance.

\subsection{Key words}

Diabetes mellitus; Obstructive sleep apnea; Neurotoxicity; Autoantibodies;Atrial fibrillation

\section{Introduction}

Obstructive sleep apnea (OSA) is characterized by sleepdisordered breathing and excessive daytime sleepiness [1]. Obstructive sleep apnea increases in adult type 2 diabetes (T2DM) and may affect as many as four in ten older men with T2DM [2]. Visceral obesity is an important underlying risk factor in OSA [3], although the mechanism for the association is not well understood. Airway patency is normally maintained by motor neuron outflow to pharyngeal dilator muscles during wakefulness and sleep [4]. Since synaptic input to pharyngeal dilator motor neurons normally decreases during sleep [4] a humoral factor which suppresses local neuronal excitability might contribute to apnea or hypopnea.

In prior studies, we reported circulating autoantibodies which altered spontaneous activity in electrically-excitable cells. The autoantibodies were increased in plasma of diabetic patients having a cluster of complications including: painful neuropathy [5], atrial fibrillation [6], major depressive disorder [7]; and in cancer fatigue/depression [5].

In the present study we tested a hypothesis that plasma IgG autoantibodies in diabetic obstructive sleep apnea cause long-lasting neuronal depolarization compared to autoantibodies in diabetic patients without obstructive sleep apnea. The mechanism of diabetic OSA autoantibodies' inhibitory effect on neurite outgrowth in N2A neuroblastoma cells was evaluating using specific antagonists of G-protein coupled receptors or the RhoA/ Rho kinase signaling pathway.

\section{Subjects and Methods}

\subsection{Diabetic obstructive sleep apnea and control patients}

Informed consent was obtained from all study patients prior to blood drawing. Patients were enrolled from the diabetes and endocrinology outpatient clinics at the Veterans Affairs New Jersey Healthcare System, East Orange, NJ. The baseline clinical characteristics in the patients whose autoantibodies were tested for ability to evoke neuronal depolarization are summarized in Table 1. Painful diabetic neuropathy is defined according to previously reported criteria [5]. Diabetic nephropathy is defined as urinary
Table 1 Baseline clinical characteristics in study participants

\begin{tabular}{|l|l|l|l|}
\hline $\begin{array}{l}\text { Risk } \\
\text { factor }\end{array}$ & $\begin{array}{l}\text { OSA } \\
(\mathbf{n}=14)\end{array}$ & $\begin{array}{l}\text { No OSA } \\
(\mathbf{n}=17)\end{array}$ & P-value^ \\
\hline $\begin{array}{l}\text { Age } \\
\text { (years) }\end{array}$ & $66.2 \pm 13.3$ & $64.6 \pm 7.7$ & 0.71 \\
\hline $\begin{array}{l}\text { BMI } \\
\text { (kg/m2) }\end{array}$ & $39.0 \pm 9.3$ & $30.5 \pm 6.6$ & 0.008 \\
\hline $\begin{array}{l}\text { Depression } \\
\text { (yes/no) }\end{array}$ & $(7 / 7)$ & $(9 / 8)$ & 1.0 \\
\hline $\begin{array}{l}\text { Nephropathy } \\
\text { (yes/no) }\end{array}$ & $(5 / 9)$ & $(2 / 15)$ & 0.2 \\
\hline $\begin{array}{l}\text { Painful neuropathy } \\
\text { (yes/no) }\end{array}$ & $(6 / 8)$ & $(6 / 11)$ & 0.72 \\
\hline $\begin{array}{l}\text { trial fibrillation } \\
\text { (yes/no) }\end{array}$ & $(7 / 7)$ & $(2 / 15)$ & 0.04 \\
\hline
\end{tabular}

OSA- obstructive sleep apnea; BMI- body mass index ^ P-value from T-test (continuous variables) or $\chi^{2}$ test (dichotomous variables) comparing patients with or without OSA.

albumin excretion $\geq 300$ milligrams/gram creatinine or urinary protein excretion $\geq 500$ milligrams/ gram creatinine. Diagnostic criteria and clinical evaluation in diabetic depression patients were previously reported [7]. A diagnosis of obstructive sleep apnea was based on chart review and included patients with concurrent use of a nasal or face-mask continuous positive airway pressure (CPAP) device at night with or without diagnostic results from overnight polysomnography testing. Moderate obstructive sleep apnea is herein defined as an apnea-hypopnea index (AHI) of 15-30 per hour; severe OSA as an AHI > 30 per hour. Morbid obesity is defined as body mass index $35-40 \mathrm{~kg} / \mathrm{m}^{2}$ or above with associated medical co-morbidities and 'super obesity' as BMI 50 $\mathrm{kg} / \mathrm{m}^{2}$ or higher.

\subsection{Obstructive sleep apnea and atrial fibrillation or demen- tia}

Pt 1: 59-year-old male with super obesity (BMI $60 \mathrm{~kg} / \mathrm{m}^{2}$ ), type 2 diabetes and obstructive sleep apnea. He suffers from paroxysmal atrial fibrillation, asthma, and pituitary macro-prolactinoma. Pt 2: 69-year-old male with morbid obesity, type 2 diabetes and severe obstructive sleep apnea. He developed atrial fibrillation with slow ventricular response requiring permanent pacemaker placement Pt 3- 68-year- old male with super obesity (BMI $58 \mathrm{~kg} / \mathrm{m}^{2}$ ), type 2 diabetes, obstructive sleep apnea and permanent atrial fibrillation. Results of overnight polysomnography testing included: apnea-hypopnea index (AHI) 34 per hour, minimum O2 saturation 88\%. Pt 4- A 68-year-old Caucasian male (with family history of Alzheimer's dementia) who suffered with obstructive sleep apnea, moderate obesity, atrial fibrillation requiring pacemaker placement, hypertension, diabetic nephropathy, painful neuropathy, and depression. The patient died of unknown causes after two-years' follow-up observation and treatment.

Pt 5- A 68-year-old Caucasian male with morbid obesity, severe obstructive sleep apnea, left ventricular hypertrophy, and hypertension. He experienced several episodes of hard syncope re- 
sulting in multiple rib fractures. He was diagnosed with bradycardia secondary to sick sinus syndrome and was treated with a dual chamber cardiac pacemaker. He underwent overnight polysomnography: apnea/ hypopnea index (AHI) was 32.8 per hour, his lowest oxygen saturation $\left(\mathrm{O}_{2}\right.$ sat) was $72 \%$ and he experienced more than 200 episodes of bradycardia with duration of 392 minutes in 456 minutes total recorded time. He was doing well until age 73 years, when he died of unknown causes.

Pt 6- A 73-year-old moderately- obese, African-American male with atrial fibrillation, OSA and glaucoma, Overnight polysomnography parameters included: AHI 33 per hour, and minimum $\mathrm{O}_{2}$ saturation $79 \%$.

Pt 7- 73-year-old obese Caucasian male with seizure disorder, OSA, and diabetic depression who later developed dementia

Pt 8- 53-year-old thin adult-onset type 1 diabetes with seizure disorder, schizophrenia, nephropathy, and dementia

Pt 9-74-year-old obese type 2 diabetes male with microalbuminuria, congestive heart failure and peripheral vascular disease

\subsection{Blood drawing}

Baseline plasma samples were obtained from study participants prior to the initiation of study procedures.

\subsection{Protein A chromatography}

Protein- A chromatography was carried out as previously described [8]. The protein-A-eluate fractions consisted of total IgG isolated from plasma upon low $\mathrm{pH}$ elution from the protein-A column. The active protein-A- eluate caused significant inhibitory activity in endothelial cell survival.

\subsection{Endothelial cell survival assay}

Bovine pulmonary artery endothelial cells (Clonetics, Inc. San Diego, CA) were grown in Medium 199 plus 10\% fetal calf serum and endothelial cell growth medium (EGM, Clonetics, Inc., San Diego, CA). Endothelial cell number assays were carried out as previously reported [8]. After 48 hours' incubation in the presence of protein-A-eluate fractions, cells were washed with PBS and processed for the colorimetric estimation of cell number, i.e. cell associated acid phosphatase activity, as previously described [8]. Growth-promoting activity is expressed as a percentage of the control cell number for cells grown in the absence of proteinA-eluate fractions.

\subsection{Mouse neuroblastoma cells}

Mouse neuroblastoma N2A cells were cultured in Dulbecco's modified Eagle's medium (DMEM), containing 10\% fetal bovine serum, (FBS) (Invitrogen, Carlsbad, CA) and penicillin/streptomycin (100 U/ mL and $100 \mathrm{mg} / \mathrm{mL}$, respectively) at $37^{\circ} \mathrm{C}$ and $5 \% \mathrm{CO}_{2}$. Cells were plated in 96 - well plates for 3 days prior to membrane depolarization experiments.

\subsection{N2A cell/ neurite out growth}

Cells were plated at low density in $35 \mathrm{~mm}$ dishes. Next recombinant human bFGF (10 ng/ mL) in the presence or absence of hu- man IgG test fractions were added to dishes in triplicate. Groups of 50-100 cells/dish were counted 2 days after the addition of test factors. Neurite outgrowth represents the percentage of N2A cells expressing more than one neurite. A neurite is defined as a cell process that is at least 2 cell diameters in length of the cell body. Results are expressed as \% N2A cells expressing neurites (which represent the mean $\pm \mathrm{SD}$ of triplicate determinations) compared to neurite expression in cells grown with $10 \mathrm{ng} / \mathrm{mL}$ human bFGF, but without added test protein-A-eluate fractions.

\subsection{Membrane depolarization assays}

After cell attachment, growth medium was removed and cells were washed and then incubated in modified Tyrode's solution consisting of: $150 \mathrm{mM} \mathrm{NaCl}, 3 \mathrm{mM} \mathrm{KCL}$ and $30 \mathrm{mM}$ HEPES, $10 \mathrm{mM}$ D-glucose and $2 \mathrm{mM} \mathrm{CaCL}_{2}, \mathrm{pH}$ 7.4. Test fractions (human IgG fractions) were added in the presence of $97 \mathrm{nM}$ DiBAC4 (Molecular Probes, Eugene, OR) - as previously reported [6]. Fluorescence was measured after 5 min or longer at room temp using a Fluoroskan Ascent FL (VWR, Inc., Franklin, MA); Ex $=485$ nm, $\mathrm{Em}=538 \mathrm{~nm}$. Results are expressed as percent of change in gross fluorescence compared to cells to which no test protein-A-eluate fractions were added.

\subsection{HL-1 cell culture}

HL-1 atrial cardiomyocytes were developed (and generously provided) by Dr. William Claycomb (Louisiana State University Medical Center, New Orleans, LA). They were maintained in 5\% $\mathrm{CO}_{2} / 95 \%$ air at $37^{\circ} \mathrm{C}$ in Claycomb media (Sigma, St. Louis, MO) containing 10\% FBS (Biocell, Rancho Dominguez, CA), 100 $\mathrm{U} / \mathrm{mL}: 100 \mathrm{ug} / \mathrm{mL}$ penicillin-streptomycin (Invitrogen, Carlsbad, CA), $0.1 \mathrm{mM}$ norepinephrine (Sigma, St. Louis, MO), and $2 \mathrm{mM}$ L-glutamine (Invitrogen, Carlsbad, CA).

\subsection{Intracellular calcium measurement}

HL-1 cells were grown in $-\delta \mathrm{T} 3$ dishes (Bioptechs, Inc., Butler, PA) and loaded with $2 \mu \mathrm{M}$ Fura-2 acetoxymethyl ester(Invitrogen, Carlsbad, CA) for $30 \mathrm{~min}$ at $37 \circ \mathrm{C}$ in a balanced salt solution (BSS) (140 mM NaCl, $2.8 \mathrm{mM} \mathrm{KCL}, 2 \mathrm{mM} \mathrm{CaCL}_{2}, 2 \mathrm{mM} \mathrm{MgCL}, 10 \mathrm{mM}$ HEPES, pH 7.2) as previously reported [6]. The cells were then left for a further 10-minute period in the bathing solution at room temperature to allow ester hydrolysis to go to completion. Using a dual-wavelength spectrofluorometer (Photon Technology International, Monmouth Junction, NJ) with excitation wavelengths at 340 and $380 \mathrm{~nm}$ and emission at $510 \mathrm{~nm}$ fluorescence measurements were performed at room temperature on the stage of an inverted fluorescence microscope (Nikon TE200). The release of intracellular $\mathrm{Ca}^{2+}$ was measured following exposure to $1 \mu \mathrm{g} /$ $\mathrm{mL}$ concentrations of the protein-A eluate(s).

\subsection{Size exclusion (gel filtration) chromatography}

G75 superfine Sephacryl (Pharmacia, Piscataway, NJ) equilibrated in $10 \mathrm{mM}$ sodium phosphate, $0.15 \mathrm{M} \mathrm{NaCl}, \mathrm{pH} 7.4$ was packed into a $5 \times 0.7 \mathrm{~cm}$ column (Sigma, St. Louis, MO) having a volume of $2.2 \mathrm{~mL}$. An aliquot of the protein- A-eluate $(0.05 \mathrm{~mL})$ 
was added to the column and eluted in $10 \mathrm{mM}$ sodium phosphate, $0.15 \mathrm{M} \mathrm{NaCl}, \mathrm{pH} 7.4$ at a flow rate of $0.22 \mathrm{~mL} / \mathrm{min}$, at $20 \circ \mathrm{C}$. Each individual collected fraction $(0.11 \mathrm{~mL})$ was assayed for effects on N2A neurite outgrowth. For the experiments involving inhibition of endogenous MT1-MMP, protein- A- eluates (100 uL) were incubated in the presence or absence of NSC $405020(200 \mu \mathrm{M})$ in $50 \mathrm{mM}$ HEPES, $\mathrm{pH} 6.8$, containing $10 \mathrm{mmCaCl}_{2}$, at $37 \circ \mathrm{C}$ for 14 hours prior to size exclusion chromatography.

\subsection{Chemicals}

Protein- A agarose was obtained from Pierce Chemical Co., (Rockford, IL). N-(2,3-diphenyl-1,2,4-thiadiazol-5-(2H)ylidene)methanaminehydrobromide (SCH-202676) and 3,4dichloro-N-(1-methylbutyl)-benzamide, (NSC 405020) were from Sigma Chem. Co., Inc. (St Louis, MO). All other chemicals and reagents were analytical grade.

\subsection{Protein determinations}

Protein concentrations were determined by a bicinchoninic acid protein assay kit (Pierce Chemical Co., Rockford, IL).

\subsection{Statistics}

All data are the mean \pm 1 SE as indicated. Comparisons were made by Student's $\mathrm{t}^{\longleftarrow}$ test for a continuous variable, or by Chisquare $\left(\chi^{2}\right)$ test for dichotomous variables with a significance level, $\mathrm{P}=0.05$.

\section{Results}

\subsection{Baseline clinical characteristics in study groups}

Body mass index was significantly increased in diabetes having obstructive sleep apnea (39.0 vs $30.3 \mathrm{~kg} / \mathrm{m}^{2}, \mathrm{P}=0.011$, Table 1) compared to age-matched diabetic patients without obstructive sleep apnea. Baseline atrial fibrillation was also significantly increased in diabetes having OSA vs. no OSA (50\% vs $11.8 \%$, P $=0.04$, Table 1).

\subsection{Depolarization induced by diabetic obstructive sleep ap- nea autoantibodies}

Autoantibodies in diabetic obstructive sleep apnea $(10 \mu \mathrm{g} / \mathrm{mL})$ caused a near doubling in the mean level of N2A depolarization (129.1 vs $115.1 \%, \mathrm{P}=0.012$, Figure 1 ) compared to identical concentrations of autoantibodies in age-matched diabetic patients without OSA. These data are the first to suggest that circulating autoantibodies in diabetes having obstructive sleep apnea cause increased neuronal depolarization.

\subsection{Neurite inhibition by diabetic obstructive sleep apnea autoantibodies}

Autoantibodies in diabetes with obstructive sleep apnea (10 $\mu \mathrm{g} / \mathrm{mL}$ ) caused significantly greater inhibition of neurite outgrowth in N2A cells (33\% vs $50 \%, \mathrm{P}=0.01$, Figure 2A) compared to identical concentrations of autoantibodies in agematched diabetic patients without OSA. Co-incubation of diabetic OSA autoantibodies ( $\mathrm{N}=5$ patients) with $(10 \mu \mathrm{M})$ concentrations

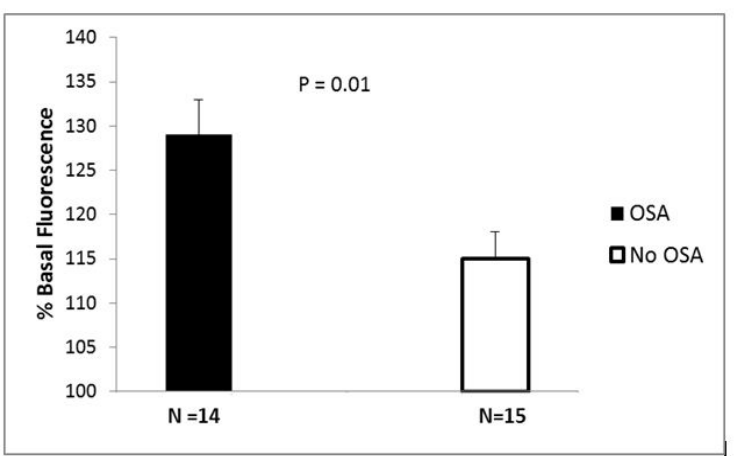

Figure 1: Diabetic obstructive sleep apnea (OSA) auto antibodies caused significantly greater mean depolarization in N2A neuroblastoma cells compared to control diabetic auto antibodies (No OSA). Results are mean +/- SE; $\mathbf{P}=$ 0.01 for the difference; $N=$ number of participants in each patient subgroup.

of the G protein- coupled receptor antagonist SCH-202676 significantly prevented $(\mathrm{P}<0.001) \mathrm{N} 2 \mathrm{~A}$ neurite inhibition from the autoantibodies (Figure 2B). Neurite outgrowth inhibition by diabetic OSA autoantibodies ( $\mathrm{N}=6$ patients) was also significantly prevented $(\mathrm{P}<0.001$ ) by co-incubating N2A cells with $10 \mu \mathrm{M}$ concentrations of the selective Rho kinase inhibitor Y27632 (Figure $2 \mathrm{C}$ ). Taken together, these results suggest involvement of one or more G-protein coupled receptor(s) and downstream RhoA/ Rho kinase signaling in the mechanism of autoantibody-mediated neurite retraction.

\subsection{Long-term storage unmasks inhibitory endothelial cell} activity in diabetic OSA protein-A eluates

In prior studies, we reported that peak EC inhibitory activity and neurotoxicity was unmasked following long-term storage (or furin treatment) in diabetic protein- A- eluates from patients having a co-morbid neurodegenerative disorder, i.e. glaucoma or dementia [9]. In the present study, storage (9-60 months at $0-4^{\circ} \mathrm{C}$ ) (n $=5$ ) unmasked significant EC inhibitory activity preferentially in diabetic OSA protein- A- eluates compared to the stored proteinA- eluates of diabetes without OSA $(n=17)$ (Table 2). Patient subgroup having diabetes plus OSA included significantly more glaucoma suspects (4/5 vs. 4/17; $\mathrm{P}=0.04$; Fischer's exact test) than the diabetes subgroup without OSA (not shown in Table 2). Potent EC- inhibitory activity was also unmasked following storage of a metastatic lung cancer protein- A- eluate $(n=1)$, or in the freshly-isolated autoantibodies from breast cancer $(n=4)$, but not in older adults without cancer or diabetes $(\mathrm{n}=3$ ) (Table 2). These data suggest a shared role for specific proteases elaborated in certain cancers (or in OSA) in unmasking latent EC inhibitory autoantibody activity.

\subsection{Peak neurite-inhibitory in diabetic OSA autoantibodies: apparent MWs}

In prior studies, peak neurotoxicity in cancer fatigue/depression [5] and diabetic depression protein-A-eluates had apparent MWs 


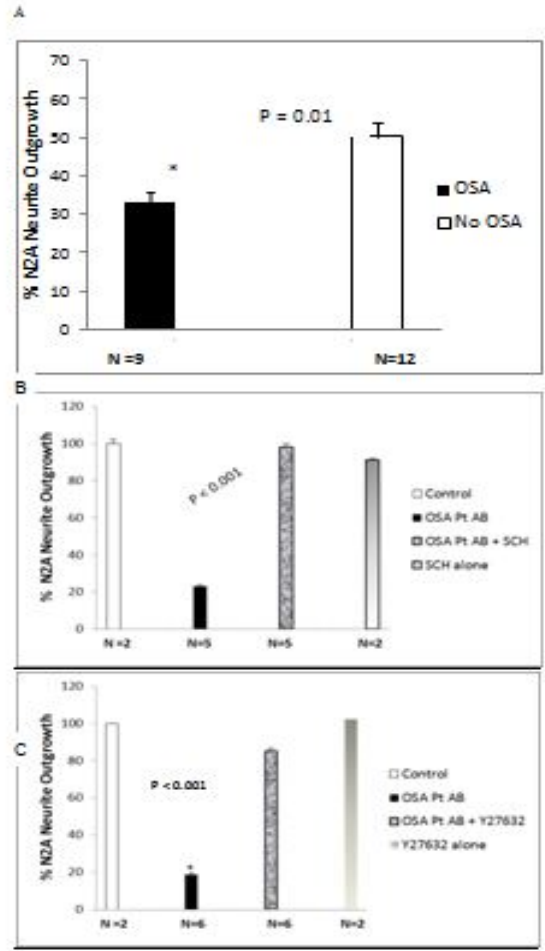

Figure 2: Diabetic obstructive sleep apnea (OSA) auto antibodies A) caused significantly greater mean inhibition of neurite outgrowth in N2A neuroblastoma cell compared to control diabetic auto antibodies (No OSA). B) Inhibition of neurite outgrowth by diabetic OSA auto antibodies $(\mathrm{N}=5$ pts) was completely blocked by co-incubation with (10 $\mu \mathrm{M})$

SCH-202676. C) Diabetic OSA auto antibodies' neurite inhibition $(\mathrm{N}=6)$ was also significantly antagonized by co-incubated N2A cell with $(10 \mu \mathrm{M})$ Y27632, a selective Rho kinase inhibitor. Results are mean $+/-\mathrm{SE}$.

corresponding to IgG light chains $(23 \mathrm{kD})$ or half -light chains $(11.5 \mathrm{kD})$ [6]. In the present study, peak neurotoxicity in diabetic OSA/atrial fibrillation protein-A-eluates, (i.e. Pts 1, 2) had apparent MWs of $\sim 22 \mathrm{kD}$, and $\sim 5.5 \mathrm{kD}$ (Figure 3A). An additional neurotoxic peak in a third diabetic OSA/AF patient had apparent MW 11 kD (Pt 3 eluate; Figure 3B).

\subsection{Diabetic OSA autoantibodies induce $\mathrm{Ca} 2+$ release in HL-1 atrial cardiomyocytes}

Protein A eluates ( $1 \mu \mathrm{g} / \mathrm{mL}$ ) from two representative diabetic patients with OSA and either atrial fibrillation (Pt 4) or symptomatic bradycardia requiring permanent pacemaker placement (Pt 5) caused large increases in intracellular $\mathrm{Ca}^{2+}$ (Figure 4AB) in atrial cardiomyocytes associated with interruption in spontaneous $\mathrm{Ca}^{2+}$ oscillations (Figure 4A-B). Autoantibody-induced intracellular $\mathrm{Ca}^{2+}$ release (in HL-1 cardiomyocytes) was present in a significantly higher proportion of diabetic patients with comorbid OSA plus atrial fibrillation or another symptomatic cardiac dysrhythmia (6/7 vs. 1/6; $\mathrm{P}=0.03$; Fischer's exact test) compared to type $2 \mathrm{DM}$ without OSA, AF or symptomatic cardiac dysrhythmia (not shown in Figure 4). In an age-matched subset of type $2 \mathrm{DM}$ having AF or left ventricular hypertrophy, peak
Table 2 Unmasking of EC inhibitory activity in protein A eluates after long-term storage

\begin{tabular}{|l|l|l|l|}
\hline \multicolumn{1}{|c|}{ Co morbidity } & \multicolumn{1}{c|}{$\begin{array}{c}\text { Before } \\
\text { storage }\end{array}$} & $\begin{array}{c}\text { After } \\
\text { storage }\end{array}$ & $\begin{array}{c}\text { P- } \\
\text { value }\end{array}$ \\
\hline $\begin{array}{l}\text { Diabetes \& } \\
\text { OSA ( } \mathrm{n}=5)\end{array}$ & $98 \pm 4 \%$ & $80 \pm 15 \%$ & 0.03 \\
\hline $\begin{array}{l}\text { Diabetes } \\
\text { without OSA(n=17) }\end{array}$ & $92 \pm 15 \%$ & $93 \pm 26 \%$ & 0.84 \\
\hline $\begin{array}{l}\text { Diabetes \& } \\
\text { Lung cancer (n=1) }\end{array}$ & $85 \pm 7 \%$ & $28 \pm 10 \%$ & 0.01 \\
\hline $\begin{array}{l}\text { Breast } \\
\text { cancer (n=4) }\end{array}$ & $66+15 \% \wedge \wedge$ & NT & \\
\hline $\begin{array}{l}\text { Non-diabetic } \\
\text { control (n=3) }\end{array}$ & $102+3 \%$ & NT & \\
\hline
\end{tabular}

T-test: comparing activity before and after storage

$\wedge \wedge \mathrm{P}=0.02$ : compared to non-diabetic controls

amplitude of $\mathrm{Ca}^{2+}$ release (in HL-1 cells) was significantly correlated with the Cornell voltage-duration product $(\mathrm{r}=0.708, \mathrm{P}=$ 0.007) (Figure 4C). The Cornell product is an estimate of the timevoltage integral of the electrocardiographic QRS complex which is useful in the ECG detection of left ventricular hypertrophy [10].

\subsection{Possible involvement of MT1-MMP in unmasking neuro- toxicity in diabetic OSA autoantibodies}

Membrane type 1 matrix metalloproteinase (MT1-MMP) is a broad spectrum proteinase implicated in prostate, breast and lung cancer invasion through its ability to degrade collagen and noncollagenous proteins in the extracellular matrix [11, 12]. MT1MMP expression also increases in adipogenesis (e.g. morbid obesity) [13], under atrial stretch conditions [14] and via effects of pro-inflammatory cytokines in vascular cells [15]. MT1-MMP has catalytic andpexin domains which bind and unfold triple helical collagen [16] prior to collagenolysis. NSC 405020 is a novel pexin domain-specific MT1-MMP inhibitor [17]. To test for involvement of MT1-MMP in the generation of neurotoxic autoantibody fragments, we incubated diabetic OSA/glaucoma (or/dementia) protein A eluates (Pt 6, 7)in the presence or absence of half-maximal inhibitory concentrations of NSC 405020 followed by gel permeation chromatography. Protein-A- eluates not exposed to NSC 405020 displayed peak neurotoxicity having an apparent MW of $\sim 5.5 \mathrm{kD}$ (Fig 5A). Protein- A- eluates exposed to NSC405020 displayed a shift in peak neurotoxicity toward a higher MW species ( $43 \mathrm{kd}$ ) (Figure 5B).

\subsection{Diurnal variation in plasma EC autoantibody growth ac- tivity}

The $25-75 \%$ ammonium sulfate pellet fraction of adult microalbuminuric diabetes plasma includes the IgG fraction and was reported to contain FGF-like, EC growth stimulatory activity [18]. Plasma EC stimulatory activity displayed a diurnal variation: peak activity (e.g. Pt 8, 9) occurred in the morning (0600 - 1000 hours) with much less, if any, stimulatory activity in the evening 


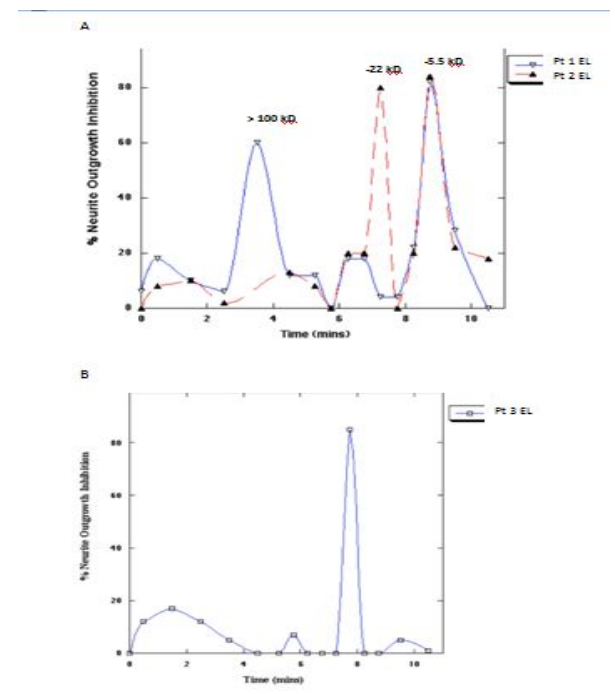

Figure 3: Size exclusion (G75 Sephacryl) chromatography of autoantibodies in three patients having diabetes, morbid obesity, atrial fibrillation and obstructive sleep apnea.A) Peak neurotoxicity in Patient 1, (pituitary prolactinoma) protein-A eluate had MWs of $>100 \mathrm{kD}$ and $5.5 \mathrm{kD}$; Patient 2 protein- A eluate had peak neurotoxicity associated with MWs of $22 \mathrm{kD}$ and $5.5 \mathrm{kD}$. B) Peak neurotoxicity in Patient 3 protein-A eluate had apparent MW of $\sim 11 \mathrm{kD}$.

(2000-2300 hours) (Figure 6A-B). Potent EC inhibitory activity was present at nighttime (2300 hours) in a 53 year old, type 1 diabetic patient suffering with co-morbid neuropsychiatric disorder and dementia (Pt 8), but not at any other time point during a 24hour sampling period (Figure 6B).

\section{Discussion}

Morbid obesity is strongly associated with obstructive sleep apnea in older men [3] and women [19] although the underlying mechanism(s) are unknown. Pro-inflammatory cytokines which increase in visceral adiposity [20] cause increased expression of inflammatory proteases, e.g. MT1-MMP [15] also implicated in cancer invasion [12]. The present data suggest involvement of an unknown G-protein coupled receptor(s) and downstream RhoA/ Rho kinase signaling in the mechanism of autoantibody-induced neurite outgrowth inhibition. Overlapping subfamilies of heterotrimeric G- proteins, (i.e. $\mathrm{G}_{q / 11}$ or $\mathrm{G}_{12 / 13}$ ) not only mediate RhoA-associated neurite retraction, but also couple to multiple downstream signaling pathways leading to IP3-mediated intracellular $\mathrm{Ca}^{2+}$ release [21] or cell depolarization [22]. Our finding of a dose-dependent association between $\mathrm{Ca}^{2+}$ release in atrial cardiomyocytes and increased left ventricular mass (QRS voltageduration) suggests the autoantibodies may be causally- related to cardiac hypertrophy. Diabetic AF/OSA autoantibodies caused quite large intracellular $\mathrm{Ca}^{2+}$ release in atrial cardiomyocytes indicative of a role in altered $\mathrm{Ca}^{2+}$ signaling underlying clinicallysignificant cardiac rhythm disturbances.

Hypertension and left ventricular hypertrophy both increase substantially in obstructive sleep apnea [23]. They cause cyclic stretch in vascular endothelial cells [24] or static stretch in atrial myocytes [25], respectively which activates MT1-MMP expression

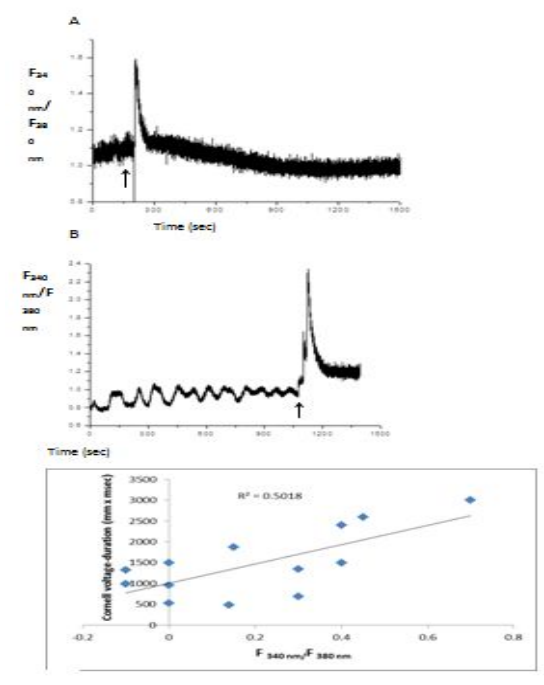

Figure 4: Representative diabetic patients with obstructive sleep apnea and either A) atrial fibrillation (Pt 4) or B) left ventricular hypertrophy, sick sinus syndrome, and symptomatic bradycardia (Pt 5) had auto antibodies which evoked (at the arrows), acute large (1.5-2.5 fold) increases in $\mathrm{Ca}^{2+}$ in HL-1 atrial cardiomyocytes. Similar results were obtained in three or more experiments. C) Plot of Cornell voltage- duration product as a function of intracellular $\mathrm{Ca}^{2+}$ release in HL-1 cells in a subset of thirteen diabetic patients with hypertension.

required for extracellular matrix remodeling. Integrin $(\beta 1)$ responds to mechanical force, e.g. stretch, by activating G12/13 family heterotrimeric G- proteins capable of activating downstream RhoA/ ROCK signaling [26]. In a prior report, diabetic EC inhibitory autoantibodies caused loss of endothelial cell adhesion in association with stress fiber activation and RhoA/ Rho kinase signaling [27]. Although the receptor is unknown, the autoantibodies may bind to site(s) in the extracellular matrix affecting HSPG-integrin interaction(s) perhaps triggering intracellular signaling events.

Glaucomatous optic atrophy is characterized by remodeling of the optic nerve head associated with increased local expression of MT1-MMP [28]. Our finding of a significant association between latent neurite inhibitory activity in diabetic OSA autoantibodies and glaucomatous cupping (i.e. glaucoma suspect) is novel and perhaps consistent with a reported association between glaucoma and OSA [29]. It suggests that tissue-specific proteolytic remodeling may contribute to optic disc neurite loss in part by unmasking (latent) neurotoxicity in a subset of circulating autoantibodies. Endothelial cell inhibitory activity in the stored or freshly-isolated protein-A eluates of plasma in metastatic lung and breast cancer (Table 2) may be consistent with elaboration of proteolytic activity, (e.g. MT1-MMP or closely-related MMPs)reported in these cancers [11,12].

Peak neurotoxicity having apparent MWs of $\sim 11 \mathrm{kD}, \sim 23 \mathrm{kD}$ and $\sim 43 \mathrm{kD}$ are characteristic of half-light chains, light chains and LC dimers, respectively. Yet more study is needed to determine whether a novel $\sim 5.5 \mathrm{kD}$ diabetic OSA autoantibody fragment is derived from specific light chains. A preliminary search 


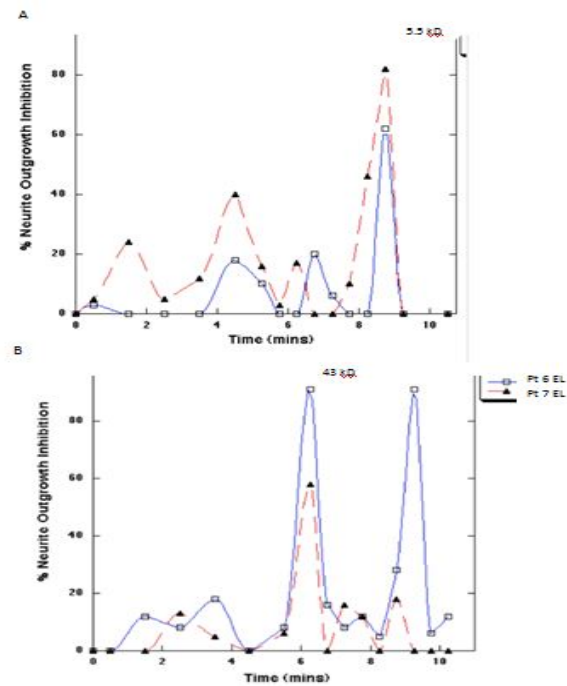

Figure 5: Size exclusion (G75 Sephacryl) chromatography of autoantibodies in two patients having diabetes, obstructive sleep apnea, and a neurodegenerative disorder, i.e. glaucoma (Pt 6), dementia and depression (Pt 7) following incubation in the absence(A) or presence (B) of a specific MT1-MMP inhibitor. A) Peak neurotoxicity in the autoantibodies incubated without MT1-MMP inhibitor had

apparent MW of $\sim 5.5 \mathrm{kD}$. B) MT1-MMP inhibition was associated with a shift in peak neurotoxicity toward higher MW species, i.e. $43 \mathrm{kD}$ perhaps corresponding to light chain dimer(s).

of database(s) of light chain variable genes revealed that lambda gene family (II or III) members (i.e. $2 \mathrm{e} 2.2$ or DPL 23)contain an unusual dibasic K-R amino acid pair at positions 52,53 in complementarity- determining region 2 (CDR2) [30]. DPL23 is a $\lambda 3$ light chain variable gene which also contains a potential MT1MMP consensus recognition sequence, P-X-G-I [31], at amino acid positions 55-58 immediately adjacent to CDR2. Cleavage near dibasic residues within CDR2 might generate a light chain fragment having the observed MW of 5-6 kD.

DPL23gene usage was reported in anti-neurotrophic viral glycoprotein antibodies such as anti-rabies [31] and anti- HIV-1 antibody light chains. The crystallographic structure of a DPL 23derived light chain component in anti-HIV-1 envelope antibodies was solved by W.D. Tolbert, X. Wu, M. Pazgierand is reported ("4fze-id,") in the Protein Database, European Pazgier and Molecular Biology Laboratory-EBI, (Welcome Genome Campus, Hinxton, Cambridge shire, UK). The light chain has a secondary structure which is rich in hydrogen-bonded, $\beta$ turns spanning the CDR2 region, i.e. amino acid residues 48-58 (Protein Database, EMBL-EBI). A postulated function of the pexin domain in MT1MMP is to disrupt hydrogen- bonding in triple helical collagen causing unfolding which permits access to the MT1-MMP catalytic domain [32]. DPL23 is among a restricted group of $\kappa$ or $\lambda$ LC genes reported to encode anti-SS-A/Ro autoantibodies, such as were isolated from salivary gland- infiltrating B cells in primary Sjogren's syndrome [33]. Evidence for antigenic selection in antiSS-A/Ro autoantibody LCs includes a somatic mutation in the Vk gene L6 which replaces asparagine $(\mathrm{N})$ at position 51 with lysine

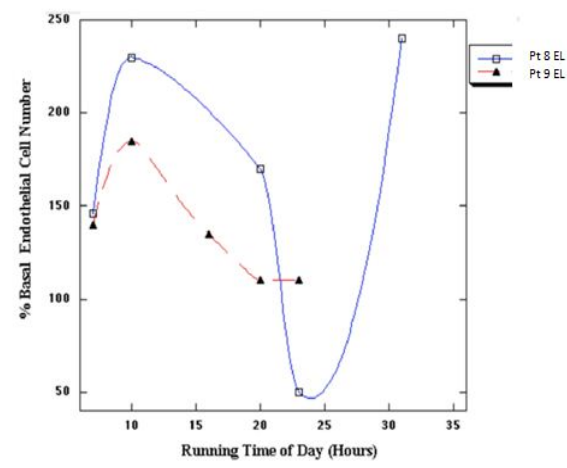

Figure 6: Diurnal variation in plasma endothelial cell growth-promoting activity in the $25-75 \%$ ammonium sulfate pellet fraction of adult type 1 or type 2 diabetes with (Pt 8) or without (Pt 9) severe co-morbid neuropsychiatric and neurodegenerative disorders. Nocturnal peak (@2300

hours) in endothelial cell inhibitory activity was specific to autoantibody-containing fraction of plasma in type 1 diabetes having neuropsychiatric/neurodegenerative co-morbidities. Protein- A eluate in Pt 8 previously caused significant inhibition of neurite outgrowth in N2A cells [6].

(K) resulting in a dibasic KR amino acid pair in CDR2, analogous to the dibasic KR pair in 'unmutated' DPL23 gene-encoded LCs. It is of interest that a subset of anti-SS-A/ Ro auto antibodies in lupus are disease-causative of neonatal congenital heart blocks [33]. Evidence for antigenic selection as a driving force in certain pathogenic autoantibody LC fragments comes from "hypermutation" in theDPL 23-derived, anti-HIV-1 envelope antibody LC ("4fze") Among other amino acid replacements, the 4fze LC CDR2 region contains an unusual aspartic acid tandem repeat (DD) aa (positions 50-51) adjacent to the conserved KR dibasic pair. Another $\lambda 3$ light chain variable gene product harboring an unusually large number of acidic and charged residues within CDR2 was reported as pathogenic in human membranoproliferative glomerulonephritis through its ability to bind and prevent complement binding to factor $\mathrm{H}$ [34]. In lupus anti-DNA antibodies, negatively-charged residues, i.e. aspartic acid, present in the $\kappa$ LC CDR1 or CDR2 regions cause reduced binding to DNA [35] which promotes self-tolerance and escape from clonal deletion. Taken together, these findings suggest that high level of inflammation (in HIV disease, cancer, systemic autoimmunity, morbid obesity)may drive immunity to self-antigens leading to the selection of a restricted subset of $\lambda$ light chain gene products prone to cleavage(by inflammatory proteases) resulting in formation of a neurotoxic fragment or fragments.

Two-fold increased neuronal depolarization evoked by diabetic OSA autoantibodies is significant. It suggests a novel humoral immune-mediated mechanism of disordered neural regulation of breathing in obstructive sleep apnea affecting older morbidlyobese type 2 diabetes. Our preliminary data showing peak plasma neurotoxicity at nighttime is of interest. One possibility is enhanced release of a protease which has a normal nocturnal pattern of expression. One such candidate is MMP2, activated by MT1-MMP, which showed increased expression at nighttime in orchestrating physiologic desquamation of surface corneal epithe- 
lial cells [36]. Continuous positive airway pressure is an established and proven effective treatment in reducing life-threatening OSA-related complications [37], however, long-term compliance with nasal or face mask CPAP may be possible in only approximately one-half of affected patients [38]. Pharmacologic modulation of the neural- mediated pathway(s) involved in nocturnal disordered breathing [39] could provide an alternative treatment approach in non-anatomic forms of obstructive sleep apnea, which requires more study.

A limitation of our study is that it may only pertain to older men with type 2 diabetes. More study is needed in women in whom morbid obesity (as opposed to anatomical upper airway narrowing) is an important contributing factor in OSA causation [19].

In summary, diabetic obstructive sleep apnea was associated with autoantibodies which caused strong depolarization in N2A cells as well as mediating neurite retraction via a G-protein coupled receptor, and RhoA/ ROCK downstream signaling pathway. A novel, low MW ( $\sim 5.5 \mathrm{kD})$ putative light chain fragment was found in diabetic OSA plasma in association with morbid obesity and complications affecting electrically-excitable tissues.

\section{Conclusion}

In conclusion, the current data suggest a novel mechanism in which circulating strongly depolarizing autoantibodies may contribute to pathophysiology in a subset of diabetic obstructive sleep apnea.

\section{Acknowledgements}

Supported by grants from the Veterans Biomedical Research Institute (East Orange, $\mathrm{NJ}$ ) to $\mathrm{MBZ}$ and from the American Diabetes Association (1-13-IN-40-BR) to ZP \& MBZ, We thank Kalashree Gopal for technical assistance.

\section{References}

1. Punjabi NM, Sorkin JD, Katzel LI, Goldberg AP, Schwartx AR, Smith PL. Sleep-disordered breathing and insulin resistance in middle-aged and overweight men. Am J RespirCrit Care Med 2002;165(5):677-682. DOI:10.1164/ajrccm.165.5.2104087.

2. Elmasry A, Lindberg E, Berne C, Janson C, Gislason T, Tageldin MA, et al. Sleep-disordered breathing and glucose metabolism in hypertensive men: a population-based study. J Intern Med. 2001;249(2):153-161.

3. Strobel RJ, Rosen RC. Obesity and weight loss in obstructive sleep apnea: a critical review. Sleep. 1996;19(2):104-115.

4. Kuna ST, Remmers JE. Neural and anatomic factors related to upper airway occlusion during sleep. Med Clin North Am. 1985;69(6):1221-1242.

5. Zimering MB, Alder J, Pan Z, Donnelly RJ. Anti-endothelial and anti-neuronal effects from auto-antibodies in subsets of adult diabetes having a cluster of microvascular complications.Diabetes Res ClinPract. 2011;93(1):95-105. doi: 10.1016/j.diabres.2011.03.029.
6.Zimering MB, Mirkovic N, Pandya M, Zimering JH, Behnke JA, et al. Toxic Immunoglobulin Light Chain Auto antibodies are Associated with a Cluster of Severe Complications in Older Adult Type 2 Diabetes. J EndocrinolDiab. 2016;3(1):1-14. DOI: dx.doi. org/10.15226/2374-6890/3/1/00141.

7. Zimering MB, Behnke JA, Thakker-Varia S, Alder J. Auto antibodies in Human Diabetic Depression Inhibit Adult Neural Progenitor Cells In vitro and Induce Depressive-Like Behavior in Rodents. J EndocrinolDiab 2015;2(2):1-11.DOI: dx.doi.org/10.15226/2374-6890/2/2/00119.

8. Zimering $\mathrm{MB}$, Thakker-Varia S. Increased fibroblast growth factor-like auto antibodies in serum from a subset of patients with cancer-associated hypercalcemia. Life Sci. 2002; 71(25):29392959. DOI: 10.1016/S0024-3205(02)02160-4.

9. Zimering MB, Moritz TE, Donnelly RJ. Anti-neurotrophic effects from autoantibodies in adult diabetes having primary open angle glaucoma or dementia. Front Endocrinol (Lausanne). 2013;4:58. Doi:10.3389/fendo.2013.00058.

10. Molloy TJ, Okin PM, Devereux RB, Kligfield P. Electrocardiographic detection of left ventricular hypertrophy by the simple QRS voltage-duration product. J Am CollCardiol. 1992;20(5):1180-1186.

11. Sato H, Seiki M. Membrane-type matrix metalloproteinases (MT-MMPs) in tumor metastasis. J Biochem. 1996;119(2):209215.

12. Okada A, Bellocq JP, Rouyer N, Chenard MP, Rio MC, Chambon P, Basset P. Membrane-type matrix metalloproteinase (MT-MMP) gene is expressed in stromal cells of human colon, breast, and head and neck carcinomas. Proc Natl AcadSci U S A. 1995;92(7):2730-2734.

13. Chun TH, Hotary KB, Sabeh F, Saltiel AR, Allen ED, Weiss SJ. A pericellular collagenase directs the 3-dimensional development of white adipose tissue. Cell. 2006;125(3):577-591.

14. Saygili E, Rana OR, Meyer C, Gemein C, Andrzejewski MG, Ludwig A, Weber C, et al.The angiotensin-calcineurin-NFAT pathway mediates stretch-induced up-regulation of matrix metalloproteinases-2/-9 in atrial myocytes Basic Res Cardiol. 2009;104(4):435-448. doi: 10.1007/s00395-008-0772-6.

15. Rajavashisth TB, Liao JK, Galis ZS, Tripathi S, Laufs U, Tripathi $\mathrm{J}$, et al. Inflammatory cytokines and oxidized low density lipoproteins increase endothelial cell expression of membrane type 1-matrix metalloproteinase. J Biol Chem. 1999;274(17):11924-11929.

16. d'Ortho MP, Will H, Atkinson S, Butler G, Messent A, Gavrilovic J,et al. Membrane-type matrix metalloproteinases 1 and 2 exhibit broad-spectrum proteolytic capacities comparable 
to many matrix metalloproteinases. Eur J Biochem. 1997; 250(3):751-757.

17. Remacle AG, Golubkov VS, Shiryaev SA, Dahl R, Stebbins JL, Chernov AV, Cheltsov AV,et al. Novel MT1-MMP small-molecule inhibitors based on insights into hemopexin domain function in tumor growth. Cancer Res. 2012;72(9):2339-2349. Doi: 10.1158/0008-5472.CAN-11-4149.

18. Zimering MB, Eng J. Increased basic fibroblast growth factor-like substance in plasma from a subset of middle-aged or elderly male diabetic patients with micro albuminuria or proteinuria. J ClinEndocrinolMetab. 1996;81(12):4446-4452.

19 Guilleminault C, Quera-Salva MA, Partinen M, Jamieson A. Women and the obstructive sleep apnea syndrome. Chest. 1988;93(1):104-109.

20. Lurie A. Inflammation, oxidative stress, and procoagulant and thrombotic activity in adults with obstructive sleep apnea. AdvCardiol. 2011;46:43-66. DOI: 10.1159/000325105.

21. Tinker A, Finlay M, Nobles M, Opel A. The contribution of pathways initiated via the Gq1 G-protein family to atrial fibrillation. Pharmacol Res. 2016;105:54-61. Doi:10.1016/j.phrs.2015.11.008.

22. Postma FR, Jalink K, Hengeveld T, Bot AG, Alblas J, de Jonge $\mathrm{HR}$, et al. Serum-induced membrane depolarization in quiescent fibroblasts: activation of a chloride conductance through the $\mathrm{G}$ protein-coupled LPA receptor. EMBO J. 1996;15(1):63-72.

23. Cloward TV, Walker JM, Farney RJ, Anderson JL. Left ventricular hypertrophy is a common echocardiographic abnormality in severe obstructive sleep apnea and reverses with nasal continuous positive airway pressure. Chest. 2003;124(2):594-601.

24. Cummins PM, von Offenberg Sweeney N, Killeen MT, Birney YA, Redmond EM, Cahill PA. Cyclic strain-mediated matrix metalloproteinase regulation within the vascular endothelium: a force to be reckoned with. Am J Physiol Heart Circ Physiol. 2007;292(1):H28-42. DOI:10.1152/ajpheart.00304.200.

25. Zile MR, Baicu CF, Stroud RE, Van Laer A, Arroyo J, Mukherjee R, et al. Pressure overload-dependent membrane type 1-matrix metalloproteinase induction: relationship to LV remodeling and fibrosis. Am J Physiol Heart Circ Physiol. 2012;302(7):H1429-1437. DOI: 10.1152/ajpheart.00580.2011.

26. Takefuji M, Krüger M, Sivaraj KK, Kaibuchi K, Offermanns S, Wettschureck N. RhoGEF12 controls cardiac remodeling by integrating $\mathrm{G}$ protein- and integrin-dependent signaling cascades. J Exp Med. 2013;210(4):665-673.

27. Zimering MB, Pan Z. Autoantibodies in type 2 diabetes induce stress fiber formation and apoptosis in endothelial cells. $\mathrm{J}$
ClinEndocrinolMetab. 2009;94(6):2171-2177.

28. Agapova OA, Kaufman PL, Lucarelli MJ, Gabelt BT, Hernandez MR.Differential expression of matrix metalloproteinases in monkey eyes with experimental glaucoma or optic nerve transection.Brain Res. 2003;967(1-2):132-43.

29. Shi Y, Liu P, Guan J, Lu Y, Su K. Association between glaucoma and obstructive sleep apnea syndrome: A meta-analysis and systematic review. PLoS ONE . 2015;10(2):e0115625. doi:10.1371/journal.pone.0115625.

30. Williams SC, Frippiat JP, Tomlinson IM, Ignatovich O, Lefranc MP, Winter G. Sequence and evolution of the human germline V lambda repertoire. J Mol Biol. 1996;264(2):220-232.

31. Ikematsu W, Kobarg J, Ikematsu H, Ichiyoshi Y, Casali P. Clonal analysis of a human antibody response. III. Nucleotide sequences of monoclonal IgM, IgG, and IgA to rabies virus reveal restricted V kappa gene utilization, junctional V kappa J kappa and V lambda J lambda diversity, and somatic hypermutation. J Immunol. 1998;161(6):2895-2905.

32. Pelman GR, Morrison CJ, Overall CM. Pivotal molecular determinants of peptidic and collagen triple helicase activities reside in the S3' subsite of matrix metalloproteinase 8 (MMP-8): the role of hydrogen bonding potential of ASN188 and TYR189 and the connecting cis bond J BiolChem. 2004;280(3):23702377. DOI:10.1074/jbc.M409603200.

33. Suzuki H, Takemura H, Suzuki M, Sekine Y, Kashiwagi H. Molecular cloning of anti-SS-A/Ro $60-\mathrm{kDa}$ peptide Fab fragments from infiltrating salivary gland lymphocytes of a patient with Sjögren's syndrome. BiochemBiophys Res Commun. 1997;232(1):101-106. DOI:10.1006/bbrc.1997.6233.

34. Jokiranta TS, Solomon A, Pangburn MK, Zipfel PF, Meri S. Nephritogenic lambda light chain dimer: a unique human miniautoantibody against complement factor H.J Immunol. 1999; 163(8):4590-4596.

35. Ibrahim SM, Weigert M, Basu C, Erikson J, Radic MZ. Light chain contribution to specificity in anti-DNA antibodies. J Immunol. 1995;155(6):3223-3233.

36. Wiechmann AF, Ceresa BP, Howard EW. Diurnal variation of tight junction integrity associates inversely with matrix metalloproteinase expression in Xenopuslaevis corneal epithelium: implications for circadian regulation of homeostatic surface cell desquamation. PLoS One. 2014;9(11):e113810. DOI: 10.1371/journal.pone.0113810.

37. Harbison J, O'Reilly P, McNicholas WT. Cardiac rhythm disturbances in the obstructive sleep apnea syndrome: effects of nasal continuous positive airway pressure therapy. Chest 2000;118:591-595. 
38. Martínez-García MA, Campos-Rodríguez F, Catalán-Serra P, Soler-Cataluña JJ, Almeida-Gonzalez C, De la Cruz Morón I, et al. Cardiovascular mortality in obstructive sleep apnea in the elderly: role of long-term continuous positive airway pressure treatment: a prospective observational study. Am J RespirCrit Care Med. 2012;186(9):909-916. DOI:10.1164/rccm.201203-0448OC.
39. Taranto-Montemurro L, Edwards BA, Sands SA, Marques M, Eckert DJ, White DP, et al. Desipramine increases genioglossus activity and reduces upper airway collapsibility during non-REM sleep in healthy subjects. Am J RespirCrit Care Med. 2016; 194(7):878-885. 